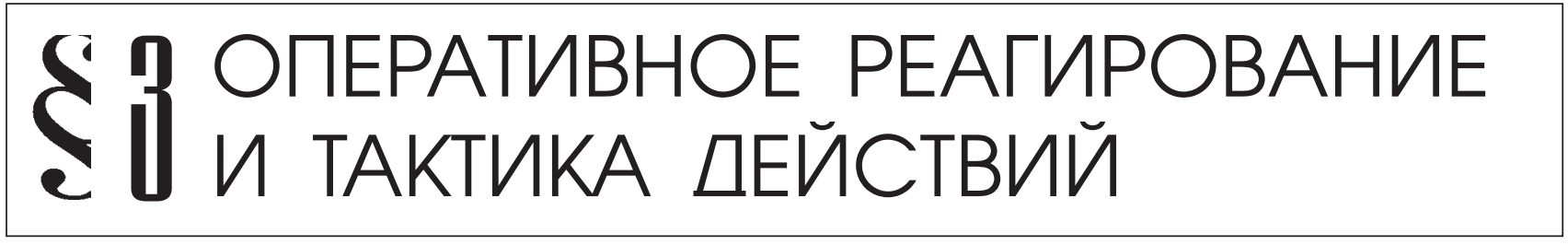

А.А. Паненков

\title{
ПОДХОД К РЕШЕНИЮ ПРОБЛЕМ БОРЬБЫ С ФИНАНСИРОВАНИЕМ ТЕРРОРИЗМА КАК ОДНОГО ИЗ ВАЖНЕЙШИХ НАПРАВЛЕНИЙ ПРОФИЛАКТИКИ В БОРЬБЕ С ТЕРРОРИЗМОМ. ПРАВОВАЯ ОСНОВА ПРОГРАММЫ ПО ВЫЯВЛЕНИЮ И РАССЛЕДОВАНИЮ ПРЕСТУПЛЕНИЙ, СВЯЗАННЫХ С ФИНАНСИРОВАНИЕМ ТЕРРОРИЗМА
}

\begin{abstract}
Аннотация: В статье автор на основе практических подходов и научных исследований 2011 г. обосновывает вывод о том, что борьба с финансированием терроризма является одним из важнейтих направлений профилактики в борьбе с терроризмом. Анализирует современную правовую основу из авторской Программы - рекомендации по выявлению и расследованию преступлений, связанных с финансированием терроризма. Ключевые слова: Юриспруденция, борьба, финансирование, терроризм, , рекомендация, проблемы, надзор, выявление, расследование, преступление.
\end{abstract}

а основе проведенных научных исследований в 2010-2011 гг. по решению проблем борьбы с финансированием терроризма (БФТ) предлагается следующая Программа ${ }^{1}-$ рекомендация $^{2}$ организации БФТ в регионе.

Программа - рекомендация по методике осуществления прокурорского надзора по выявлению и расследованию преступлений, связанных с финансированием терроризма

Введение. Выявление преступлений, связанных с финансированием терроризма, возможно следу-

\footnotetext{
${ }^{1}$ Программа- 1)план намеченной деятельности, работ, 2) изложение основных задач и целей. Учебная программа- краткое систематическое изложение содержания обучения по определенному предмету, круг знаний, умений и навыков, подлежащих усвоению. Словарь иностранных слов. Москва.1989. С.410.

2 Рекомендация - 1)письменный или устный благоприятный отзыв, 2) совет, указание. Словарь иностранных слов. Москва.1989. С.436. Программа-рекомендация по БФТ - система указаний по БФТ.
}

ющими способами: а) оперативным, б) следственным, в) следственно-оперативным, г) оперативноследственным, д) иными способами (например, в результате деятельности прокурора по надзору за исполнением законов о противодействии терроризму, Росфинмониторингом, нотариусами, адвокатами, лицами, осуществляющими предпринимательскую деятельность в сфере оказания юридических, аудиторских или бухгалтерских услуг и т.д.) $)^{3}$.

Выявление и расследование преступлений, связанных с финансированием терроризма, имеет общие особенности, присущие расследованию террористических преступлений в целом, а именно: 1. Сложность сбора и дефицит доказательств по делу: задержание с поличным курьеров при доставке денег для финансирования терроризма практически невоз-

\footnotetext{
${ }^{3}$ «Модельный закон о противодействии финансированию терроризма». Информационный бюллетень. Межпарламентская Ассамблея государств-участников Содружества Независимых Государств. 2007. N 39 (часть 1). С. 254 - 281. Принят в г. Санкт-Петербурге 16.11.2006 Постановлением 27-6 на 27-ом пленарном заседании Межпарламентской Ассамблеи государств-участников СНГ.
} 


\section{Оперативное реагирование и тактика действий}

можно. Деньги, предназначенные для финансирования терроризма, как правило, уже израсходованы или находятся у адресата, на момент получения оперативной информации или возбуждения уголовного дела. 2. Основным источником доказательств, как правило, являются показания подозреваемого, обвиняемого, задержанного за террористическую деятельность в ходе боестолкновений, или оперативно-розыскных мероприятий (ОРМ), проведенных субъектами ОРМ, или в ходе оперативно - боевых мероприятий (ОБМ) военнослужащими Министерства обороны Российской Федерации (Главного разведывательного управления Генерального Штаба - ГРУ ГШ), Внутренних войск МВД Российской Федерации, ФСБ России. 3. Недостаточная теоретическая и практическая подготовленность следователей Следственного комитета Российской Федерации (СК РФ), Следственного комитета МВД Российской Федерации, Следственной службы ФСБ России к расследованию преступлений, связанных с финансированием терроризма. 4. Низкая эффективность взаимодействия оперативных подразделений ГРУ ГШ, ФСБ России, МВД России, Росфинмониторинга со следственными подразделениями правоохранительных органов: при большом количестве оперативно-значимой информации по финансированию терроризма, она оставалась неизвестной подавляющему большинству следователей и не реализовывалась в конкретных уголовных делах. 5. Отсутствие должного уровня взаимодействия и координации действий правоохранительных органов и спецслужб России со следственными управлениями Следственного комитета (СУ СК) Российской Федерации, направленного на решение проблем выявления, возбуждения, расследования и направления в суд уголовных дел, связанных с финансированием терроризма.

Организованная экономическая преступность на Северном Кавказе и в других субъектах РФ является внутренним источником финансирования терроризма. Согласны с этим мнением 107 (48,9\%) респондентов, не согласны 83 (37,9\%), иное мнение высказали - 29 или $13,2 \%$ респондентов.

Поэтому необходимо всем правоохранительным органам и спецслужбам России бороться, в том числе с организованной экономической преступностью, разрушая финансовую основу организованной террористической деятельности.

По мнению экспертов из числа сотрудников правоохранительных органов (следователи, прокуроры, сотрудники полиции), опрошенных в 2010-2011 гг., целесообразно создание в регионах со сложной криминальной ситуаций (СКФО, Москве и других) специальных подразделений по расследованию только преступлений террористического характера и их финансирования, а также приостановленных уголовных дел террористического характера. За период с 2002 по 2003 годы не было зарегистрировано преступлений, квалифицируемых по ст. 205.1 УК РФ. В 2004 г. было уже зарегистрировано 5 преступлений. Только, начиная с 2007 г., в сводном отчете по России за январь-декабрь появился Раздел 2. «Сведения о преступлениях, связанных с террористической деятельностью» и в нем графа - «связанных с финансированием акта терроризма либо террористической организации», содержащая сведения о 4 расследованных сотрудниками органов внутренних дел преступлениях. В 2008 г. было зарегистрировано 6 расследованных преступлений, из которых 5 сотрудниками органов внутренних дел. Не произошло роста числа этих преступлений в 2009 г.: из 5 предварительно расследованных преступлений, сотрудниками органов внутренних дел расследованы - 2, в 2010 г.-предварительно расследовано одно преступление сотрудниками ОВД. Таким образом, за 2007 - 2010 г. всего было расследовано 16 преступлений, связанных с финансированием акта терроризма либо террористической организации, из которых 12 - сотрудниками органов внутренних дел. За 6 месяцев 2011 года предварительно расследовано 2 преступления, связанных с финансированием акта терроризма либо террористической организации, сотрудниками ОВД ${ }^{4}$. Согласно данным судебной статистики, за 2006 - 2010 г. по ст. 205.1 УК РФ было всего осуждено 24 лица, из которых 12 - по основной статье, 12 - по дополнительной 5 .

На 1 этапе исследования в 2010 г. анализ анкетирования следователей СК РФ, СУ СК Республик Дагестан и Ингушетия, Чеченской Республики, деятельности Росфинмониторинга позволил сделать ряд предложений-рекомендаций для совершенствования борьбы с финансированием терроризма (БФТ), которые заключались в следующем: 1.Все право-

\footnotetext{
${ }^{4}$ Выборочные данные из формы 282 за январь-июнь 2011 года. Раздел 2. Сведения о преступлениях, связанных с террористической деятельностью.

5 Данные из формы №10 а представлены старшим научным сотрудником отдела проблем информационно-аналитического обеспечения деятельности органов прокуратуры, советником юстиции Колесниковой Н.В.
} 


\section{Национальная безопасность 2(25) • 2013}

охранительные органы и спецслужбы Российской Федерации должны иметь базу данных о лицах, занимающихся террористической деятельностью в каждом субъекте (независимо от возбужденного уголовного дела), а также: 1) установочные данные о близких родственниках осужденных ${ }^{7}$, подозреваемых в организованной террористической деятельности, женах и их родственниках, «ближних связях», 2) установочные данные, списки «черных вдов» (жен погибших боевиков) и «невест аллаха», а также их родственников и ближних связях, 3) установочные данные о ближайшем окружении руководства «Эмирата Кавказ» Д. Умарова и их ближних связях, через которые могут поступать денежные средства, а также еще 18 террористических организаций, признанных Верховным Судом Российской Федерации таковыми, и деятельность которых запрещена в России, 4) установочные данные о ближайших родственниках, женах (гражданский брак, фактические брачные отношения), ближних связей «террористовсмертников» и лиц, погибших в ходе ожесточенного вооруженного сопротивления федеральным силам, 5) установочные данные лиц, въезжавших, выезжавших и выезжающих за рубеж на Ближний Восток для обучения, с коммерческими целями, и которые являлись или могли являться потенциальными курьерами по доставке денежных средств в организованные группы, НВФ, преступные организации и сообщества, банды, 6) установочные данные лиц, находящихся за границей, занимающихся коммерческой деятельностью, и связанных с организованной преступной деятельностью, включая террористическую. После анализа имеющейся информации, направлять оперативные задания в Росфинмониторинг для всесторонней проверки открытия и закрытия счетов в банках и движения денежных средств на них, поступления и отправления денежных переводов, приобретения дорогостоящих домов, автомашин и т.д., а также в Национальное центральное бюро (НЦБ) Интерпола МВД России. 2. Всем правоохранительным органам и спецслуж-

\footnotetext{
6 Установочные данные включают: Ф.И.О., дата и место рождения, род, тейп, ближние связи с участниками или организаторами организованной террористической деятельности, место жительства и место регистрации, место работы, образование, сведения о судимости, паспортные данные (включая заграничный паспорт), данные водительского удостоверения.

${ }^{7}$ Направлять оперативные задания в ИТУ по месту отбывания наказания осужденных за террористические преступления.
}

бам России следует направлять в конфиденциальном режиме в Росфинмониторинг оперативные задания по проверке конкретных лиц из ближнего окружения лидеров международных террористических организаций, включая «Эмират Кавказ» (всего 19 в России), амиров джамаатов и т.д. на предмет выяснения: a) получение и отправление денежных переводов из других субъектов Российской Федерации, ближнего и дальнего зарубежья, б) регистрации на их фамилии (паспорту) различных коммерческих структур, как в регионах активной террористической деятельности, так и в других субъектах РФ, в) открытия и закрытия счетов в банках, приобретения дорогостоящих домов, автомашин и т.д. В настоящее время источники и каналы финансирования терроризма имеют не только нелегальный, но и легальный (законный) характер: например, торгово - закупочная, строительная деятельность, автосервис в любом регионе России и направление денежных средств переводами. 3. Росфинмониторинг в режиме секретности на основе анализа и обобщения этих оперативных заданий, проводит проверки, в том числе силами своих сотрудников в Федеральных округах, и незамедлительно представляет полученные сведения инициаторам запросов. В целях повышения эффективности представляется целесообразным наделение Росфинмониторинга полномочиями субъекта ОРД.

Сотрудникам правоохранительных органов и спецслужб России следует иметь в виду, что суммы и виды операций, подлежащих обязательному контролю, регламентируются национальным законодательством. Согласно статьи 6. Операции с денежными средствами или иным имуществом, подлежащие обязательному контролю (Федеральный закон от 07.08.2001 N 115-Ф3 «О противодействии легализации (отмыванию) доходов, полученных преступным путем, и финансированию терроризма», в ред. Федерального закона от 30.10.2002 N 131-Ф3). 1. Операция с денежными средствами или иным имуществом подлежит обязательному контролю, если сумма, на которую она совершается, равна или превышает 600000 рублей либо равна сумме в иностранной валюте, эквивалентной 600000 рублей, или превышает ее, а по своему характеру данная операция относится к одному из следующих видов операций: 1) операции с денежными средствами в наличной форме: снятие со счета или зачисление на счет юридического лица денежных средств в наличной форме в случаях, если это не обусловлено характером его хозяйственной деятельности; покупка или 


\section{Оперативное реагирование и тактика действий}

продажа наличной иностранной валюты физическим лицом; (в ред. Федерального закона от 28.07.2004 N 88-ФЗ), приобретение физическим лицом ценных бумаг за наличный расчет; получение физическим лицом денежных средств по чеку на предъявителя, выданному нерезидентом; обмен банкнот одного достоинства на банкноты другого достоинства; внесение физическим лицом в уставный (складочный) капитал организации денежных средств в наличной форме; 2) зачисление или перевод на счет денежных средств, предоставление или получение кредита (займа), операции с ценными бумагами в случае, если хотя бы одной из сторон является физическое или юридическое лицо, имеющее соответственно регистрацию, место жительства или место нахождения в государстве (на территории), которое (которая) не выполняет рекомендации Группы разработки финансовых мер борьбы с отмыванием денег (ФАТФ), либо, если указанные операции проводятся с использованием счета в банке, зарегистрированном в указанном государстве (на указанной территории). Перечень таких государств (территорий) определяется в порядке, устанавливаемом Правительством Российской Федерации с учетом документов, издаваемых Группой разработки финансовых мер борьбы с отмыванием денег (ФАТФ), и подлежит опубликованию; (пп. 2 в ред. Федерального закона от 23.07.2010 N 176-Ф3). 3) операции по банковским счетам (вкладам): размещение денежных средств во вклад (на депозит) с оформлением документов, удостоверяющих вклад (депозит) на предъявителя; открытие вклада (депозита) в пользу третьих лиц с размещением в него денежных средств в наличной форме; перевод денежных средств за границу на счет (вклад), открытый на анонимного владельца, и поступление денежных средств из-за границы со счета (вклада), открытого на анонимного владельца; зачисление денежных средств на счет (вклад) или списание денежных средств со счета (вклада) юридического лица, период деятельности которого не превышает трех месяцев со дня его регистрации, либо зачисление денежных средств на счет (вклад) или списание денежных средств со счета (вклада) юридического лица в случае, если операции по указанному счету (вкладу) не производились с момента его открытия; 4) иные сделки с движимым имуществом: помещение драгоценных металлов, драгоценных камней, ювелирных изделий из них и лома таких изделий или иных ценностей в ломбард; (в ред. Федерального закона от 19.07.2007 N 197-ФЗ), выплата физическому лицу страхового возмещения или получение от него страховой премии по страхованию жизни или иным видам накопительного страхования и пенсионного обеспечения; получение или предоставление имущества по договору финансовой аренды (лизинга); переводы денежных средств, осуществляемые некредитными организациями по поручению клиента; скупка, купля-продажа драгоценных металлов и драгоценных камней, ювелирных изделий из них и лома таких изделий; получение денежных средств в виде платы за участие в лотерее, тотализаторе (взаимном пари) и иных основанных на риске играх, в том числе в электронной форме, и выплата денежных средств в виде выигрыша, полученного от участия в указанных играх; (в ред. Федерального закона от 28.07.2004 N 88-Ф3) предоставление юридическими лицами, не являющимися кредитными организациями, беспроцентных займов физическим лицам и (или) другим юридическим лицам, а также получение такого займа. (абзац введен Федеральным законом от 28.07.2004 N 88-Ф3)

1.1. Сделка с недвижимым имуществом подлежит обязательному контролю, если сумма, на которую она совершается, равна или превышает 3000000 рублей либо равна сумме в иностранной валюте, эквивалентной 3000000 рублей, или превышает ее (п. 1.1 введен Федеральным законом от 28.07.2004 N 88-ФЗ). 2. Операция с денежными средствами или иным имуществом подлежит обязательному контролю в случае, если хотя бы одной из сторон является организация или физическое лицо, в отношении которых имеются полученные в установленном в соответствии с настоящим Федеральным законом порядке сведения об их причастности к экстремистской деятельности или терроризму, либо юридическое лицо, прямо или косвенно находящееся в собственности или под контролем таких организации или лица, либо физическое или юридическое лицо, действующее от имени или по указанию таких организации или лица.

Порядок определения и доведения до сведения организаций, осуществляющих операции с денежными средствами или иным имуществом, перечня таких организаций и лиц устанавливается Правительством Российской Федерации. При этом сведения об организациях и лицах, включенных в указанный перечень по основаниям, предусмотренным подпунктами 1, 2, 3, 6, 7 пункта 2.1 настоящей статьи, и исключенных из указанного перечня по основаниям, предусмотренным подпунктами 1,2 , $3,5,6,7$ и 8 пункта 2.2 настоящей статьи, подлежат 


\section{Национальная безопасность 2(25) • 2013}

размещению в сети Интернет на официальном сайте уполномоченного органа и опубликованию в официальных периодических изданиях, определенных Правительством Российской Федерации (п. 2 в ред. Федерального закона от 27.07.2010 N 197-ФЗ).

2.1. Основаниями для включения организации или физического лица в перечень организаций и физических лиц, в отношении которых имеются сведения об их причастности к экстремистской деятельности или терроризму, являются: 1) вступившее в законную силу решение суда Российской Федерации о ликвидации или запрете деятельности организации в связи с ее причастностью к экстремистской деятельности или терроризму; 2) вступивший в законную силу приговор суда Российской Федерации о признании лица виновным в совершении хотя бы одного из преступлений, предусмотренных статьями 205, 205.1, 205.2, 206, 208, 211, 220, 221, 277, 278, $279,280,282,282.1,282.2$ и 360 Уголовного кодекса Российской Федерации; 3) решение Генерального прокурора Российской Федерации, подчиненного ему прокурора или федерального органа исполнительной власти в области государственной регистрации (его соответствующего территориального органа) о приостановлении деятельности организации в связи с их обращением в суд с заявлением о привлечении организации к ответственности за экстремистскую деятельность; 4) процессуальное решение о признании лица подозреваемым в совершении хотя бы одного из преступлений, предусмотренных статьями 205, 205.1, 205.2, 206, 208, $211,220,221,277,278,279,280,282,282.1,282.2$ и 360 Уголовного кодекса Российской Федерации; 5) постановление следователя о привлечении лица в качестве обвиняемого в совершении хотя бы одного из преступлений, предусмотренных статьями 205, 205.1, 205.2, 206, 208, 211, 220, 221, 277, 278, $279,280,282,282.1,282.2$ и 360 Уголовного кодекса Российской Федерации; 6) составляемые международными организациями, осуществляющими борьбу с терроризмом, или уполномоченными ими органами и признанные Российской Федерацией перечни организаций и физических лиц, связанных с террористическими организациями или террористами; 7) признаваемые в Российской Федерации в соответствии с международными договорами Российской Федерации и федеральными законами приговоры или решения судов и решения иных компетентных органов иностранных государств в отношении организаций или физических лиц, осуществляющих террористическую деятельность. (п. 2.1 введен Федеральным законом от 27.07.2010 N 197-ФЗ).

2.2. Основаниями для исключения организации или физического лица из перечня организаций и физических лиц, в отношении которых имеются сведения об их причастности к экстремистской деятельности или терроризму, являются:1) отмена вступившего в законную силу решения суда Российской Федерации о ликвидации или запрете деятельности организации в связи с ее причастностью к экстремистской деятельности или терроризму и прекращение производства по делу; 2) отмена вступившего в законную силу приговора суда Российской Федерации о признании лица виновным в совершении хотя бы одного из преступлений, предусмотренных статьями 205, 205.1, 205.2, 206, 208, $211,220,221,277,278,279,280,282,282.1,282.2$ и 360 Уголовного кодекса Российской Федерации, и прекращение производства по уголовному делу в отношении данного лица по основаниям, дающим право на реабилитацию; 3) отмена решения Генерального прокурора Российской Федерации, подчиненного ему прокурора или федерального органа исполнительной власти в области государственной регистрации (его соответствующего территориального органа) о приостановлении деятельности организации в связи с привлечением к ответственности за экстремистскую деятельность; 4) прекращение уголовного дела или уголовного преследования в отношении лица, подозреваемого или обвиняемого в совершении хотя бы одного из преступлений, предусмотренных статьями 205, 205.1, 205.2, 206, 208, 211, 220, 221, 277, 278, $279,280,282,282.1,282.2$ и 360 Уголовного кодекса Российской Федерации; 5) исключение организации или физического лица из составляемых международными организациями, осуществляющими борьбу с терроризмом, или уполномоченными ими органами и признанных Российской Федерацией перечней организаций и физических лиц, связанных с террористическими организациями или террористами; 6) отмена признаваемых в Российской Федерации в соответствии с международными договорами Российской Федерации и федеральными законами приговоров или решений судов и решений иных компетентных органов иностранных государств в отношении организаций или физических лиц, осуществляющих террористическую деятельность; 7) наличие документально подтвержденных данных о смерти лица, включенного в перечень организаций и физических 


\section{Оперативное реагирование и тактика действий}

лиц, в отношении которых имеются сведения об их причастности к экстремистской деятельности или терроризму; 8) наличие документально подтвержденных данных о погашении или снятии судимости с лица, осужденного за совершение хотя бы одного из преступлений, предусмотренных статьями 205, 205.1, 205.2, 206, 208, 211, 220, 221, 277, 278, 279, 280, 282, 282.1, 282.2 и 360 Уголовного кодекса Российской Федерации. (п. 2.2 введен Федеральным законом от 27.07.2010 N 197-Ф3).

3. В случае, если операция с денежными средствами или иным имуществом осуществляется в иностранной валюте, ее размер в российских рублях определяется по официальному курсу Центрального банка Российской Федерации, действующему на дату совершения такой операции.

4. Сведения об операциях с денежными средствами или иным имуществом, подлежащих обязательному контролю, представляются непосредственно в уполномоченный орган организациями, осуществляющими операции с денежными средствами или иным имуществом ${ }^{8}$.

Можно выделить ряд особенностей, существенно осложняющих выявление и расследование преступлений террористического характера и финансирование терроризма в Российской Федерации: 1.Сложная криминальная ситуация в некоторых субъектах СКФО: в Республиках Дагестан и Ингушетия, в Чеченской Республике, в КабардиноБалкарской Республике и т.д. 2.Местное население не желает активно сотрудничать с правоохранительными органами и спецслужбами России в субъектах СКФО, потому, что они не могут обеспечить полную безопасность заявителей, свидетелей и потерпевших, а также по причине реальных угроз со стороны участников организованных преступных формирований (ОПФ), которые незамедлительно их реализовывали, вплоть до убийства, подрыва

\footnotetext{
8 Федеральный закон от 07.08.2001 N 115-Ф3 (ред. от 27.06.2011) «О противодействии легализации (отмыванию) доходов, полученных преступным путем, и финансированию терроризма»(в ред. Федеральных законов от 25.07.2002 N 112-Ф3, от 30.10.2002 N 131-Ф3, от 28.07.2004 N 88-Ф3, от 16.11.2005 N 145-Ф3, от 27.07.2006 N 147-Ф3, от 27.07.2006 N 153-Ф3, от 12.04.2007 N 51-Ф3, от 19.07.2007 N 197-Ф3, от 24.07.2007 N 214-Ф3, от 28.11.2007 N 275-Ф3, от 03.06.2009 N 121-Ф3, от 17.07.2009 N 163-Ф3, от 05.07.2010 N 153-Ф3, от 23.07.2010 N 176-Ф3, от 27.07.2010 N 197-Ф3, от 27.06.2011 N 162-Ф3). Первоначальный текст документа опубликован в изданиях «Российская газета», N 151-152, 09.08.2001, «Собрание законодательства РФ», 13.08.2001, N 33 (часть I), ст. 3418.
}

автомашины, жилища, убийства или похищения как самих заявителей, так и близких родственников. Федеральный закон о государственной защите свидетелей, потерпевших и других участников уголовного судопроизводства, в полном объеме не действует, особенно в субъектах СКФО. 3. В силу этнической и конфессиональной сплоченности населения проведение разведывательных, контрразведывательных и оперативно-розыскных мероприятий, крайне затруднено: в эту среду трудно внедрить агентурный аппарат или получить оперативно-значимую информацию. Таким агентом, может быть, только соплеменник, имеющий стойкую мотивацию для разобщения ОПФ террористического характера и нейтрализацию их лидеров, непримиримых участников, например, кровная месть, корыстный интерес. 4. Следует отметить недостаточный уровень профессиональной подготовки сотрудников правоохранительных органов титульной нации, в частности оперативных сотрудников полиции, ФСКН при организации и проведении ОРМ и следственных действий. 5.Правоохранительным органам и спецслужбам субъектов СКФО приходится работать в обстановке жесткого контроля (прессинга) со стороны международных и российских общественных правозащитных организаций и СМИ. 6. Сложность сбора доказательств по фактам финансирования терроризма затруднена ввиду высокой латентности, конспиративного характера этой деятельности. Задерживать с поличным курьеров, доставлявших деньги или другое имущество, для финансирования организованной террористической деятельности, не удавалось. Как правило, обвинение строилось на показаниях свидетелей, расшифровках радиоперехватов, «черновых записей», электронных носителей нейтрализованных лидеров организованных преступных формирований. 7. Борьба с терроризмом, и его финансированием носит транснациональный характер, выходит за пределы одного-двух государств (отсюда терминология: борьба с мировым терроризмом и экстремизмом, борьба с международным финансированием терроризма и экстремизма и т.д.) и наиболее эффективна при надлежащем уровне координации и взаимодействия всех правоохранительных органов и спецслужб России (всех субъектов ОРД), с коллегами аналогичных служб за границей, в первую очередь, для получения упреждающей информации в результате проведения разведывательных, контрразведывательных и оперативно-розыскных 


\section{Национальная безопасность 2(25) • 2013}

мероприятий 9 . 8. Несовершенство действующего законодательства порождает проблемы квалификации финансирования терроризма. Тем не менее, в науке уже высказаны пути решения этих проблем. Например, если лицо содействует совершению преступлений, предусмотренных ст.ст. 205, 205.1, 205.2, 206, 208, 211, 220, 221, 277, 278, 279, 360 УК РФ, собиранием или предоставлением денежных средств или иного имущества либо оказанием финансовых услуг, предназначенных для их финансирования, его действия полностью охватываются ст. 205.1 УК РФ и не требуют дополнительной квалификации по другим статьям УК РФ.

Другая ситуация возникает, когда финансирование преступления террористического характера входит в состав действий лица по организации его совершения. Здесь финансирование терроризма не является конструктивным признаком организации преступлений террористического характера, поскольку не предусмотрено ч. 3 ст. 33 УК РФ, поэтому подлежит самостоятельной квалификации по совокупности преступлений. В тех случаях, когда лицо, исполняя роль организатора преступления террористического характера, одновременно осуществляет его финансирование, содеянное следует квалифицировать как совокупность преступлений, предусмотренных ст. 205.1 УК РФ и соответствующей статьей УК РФ об ответственности за преступления террористического характера со ссылкой на ч. 3 ст. 33 УК РФ.

Аналогичным образом должны разрешаться вопросы, связанные с квалификацией действий лица по финансированию организованной группы, созданной для совершения преступлений, предусмотренных ст.ст. 205, 205.1, 205.2, 206, 208, 211, 220 , 221, 277, 278, 279, 360 УК РФ, то есть: если лицо не является членом указанной организованной группы, но оказывает содействие ее террористической деятельности путем финансирования, оно подлежит уголовной ответственности только по ст. 205.1 УК РФ. В противном случае лицо должно нести уголовную ответственность за конкретные преступления террористического характера, в подготовке или совершении которых он участвовал. Если лицо осуществляет финансирование указанной организованной группы в рамках ее общего руководства,

\footnotetext{
${ }^{9}$ Мельник Т. В. Международно-правовое регулирование борьбы с финансированием терроризма на универсальном уровне. Автореферат. Москва.2010.
}

оно несет ответственность по совокупности преступлений - за каждое совершенное организованной группой преступление террористического характера, если оно охватывалось его умыслом, и за финансирование терроризма ${ }^{10} .9$. Отсутствие значительной судебно-следственной практики. Таким образом, за 2007 - 2010 г. всего было расследовано 16 преступлений, связанных с финансированием акта терроризма либо террористической организации, из которых 12 - сотрудниками органов внутренних дел. За 6 месяцев 2011 года предварительно расследовано 2 преступления, связанных с финансированием акта терроризма либо террористической организации, сотрудниками ОВД ${ }^{11}$. Можно отметить, что в 2011 г. произошел своеобразный «скачок» в выявлении фактов финансирования терроризма. Так, в первом полугодии 2011 г. только в Северо - Кавказском федеральном округе было выявлено 50 преступлений (РФ-52), связанных с содействием террористической деятельности, которые предусмотрены ст. 205.1 УК РФ. Количество предварительно расследованных преступлений по ст.205.1 УК РФ в январе-июне 2011 года в России было 38, из которых, связанных с финансированием террористического акта либо террористической организации только $-2^{12}$. За 9 месяцев 2011 года по ст.205.1 УК РФ расследовано и направлено в суд 3 дела следователями СК РФ (9 мес.2010 г. - 4 дела: следователями СК-0, ОВД2) на 5 обвиняемых (9 мес. 2010г. - 4 обвиняемых: следователями СК-0, ОВД-2) ${ }^{13}$. 10. Бандиты уже не

\footnotetext{
${ }^{10}$ Ульянова В.В. Противодействие финансированию терроризма. Автореферат диссертации на соискание ученой степени кандидата юридических наук: Свердловск. 2010. Так, по мнению диссертанта, финансирование терроризма, совершенное путем предоставления или сбора средств, следует признавать оконченным с момента начала предоставления или сбора средств, независимо от того, дошли они до получателя и фактического их использования.

${ }^{11}$ Выборочные данные из формы 282 за январь-июнь 2011 года. Раздел 2. Сведения о преступлениях, связанных с террористической деятельностью.

${ }^{12}$ Сводный отчет по России «О преступлениях террористического характера, экстремистской направленности и связанных с террористической деятельностью за январь-июнь 2011 года».

${ }^{13}$ Приложение № 1 к приказу Генерального прокурора Российской Федерации от 28.05.2010 № 226. Сведения о работе прокурора по надзору за исполнением законов о федеральной безопасности, межнациональных отношениях и противодействии экстремизму и о результатах расследования уголовных дел экстремистской и террористической направленности за январь-июнь 2011 года (нарастающим итогом). За 9 мес. 2011
} 
ограничиваются денежными поборами с предпринимателей, они предъявляют финансовые требования к руководителям органов власти ${ }^{14}$.

НИИ Академии Генеральной прокуратуры Российской Федерации было проведено в 2010-2011 гг. 2 этапа научных исследований по БФТ ${ }^{15}$. На основе исследований сотрудникам правоохранительных органов была предложена следующая программа борьбы с терроризмом и его финансированием. На вопрос о том, согласны ли Вы с такой программой борьбы с терроризмом в 2011 г., ответы респондентов распределились следующим образом: «Да»- 143 (67,8\%), «нет»- 47 (22,3\%), иное мнение высказали $21(10,0 \%)$, всего ответили 211 лиц ${ }^{16}$. Можно привести следующий спектр мнений экспертов по БФТ:

Взаимодействием с Росфинмониторингом по борьбе с финансированием терроризма: не удовлетворены -124 (54,9\%), нет взаимодействия - 43 (19,0\%), удовлетворены - 42 (18,6\%), иное -17 (7,5\%).

года прекращено по ст.205-1 УК РФ -1 дело (9 мес.2010 г.-0), следователем СК РФ-1 (9 мес.2010 г.-0), следователем ОВД -0 (9 мес.2010 г.-0). Число лиц, в отношении которых прекращено преследование по ст.205.1 УК РФ: 9 мес.2011 г.-2 лица (9 мес.2010 года-0), следователем СК РФ-2 (9 мес.2010 г.-0), следователем ОВД -0 (9 мес.2010 г.-0). Количество приостановленных дел по ст.205.1 УК РФ: 9 мес.2011 г.-2 (9 мес.2010 г.-0).

${ }^{14}$ Вестник Национального антитеррористического комитета. Специальный выпуск. №2(4).2011. С.12. Из доклада Директора ФСБ России А.В. Бортникова.

${ }^{15}$ В период служебной командировки работников НИИ Академии Генеральной прокуратуры Российской Федерации с 16 по 29 мая 2011 года было организовано и проведено анкетирование сотрудников правоохранительных органов, спецслужб, студентов Республики Ингушетия, Чеченской Республики и Республики Дагестан по актуальным вопросам БФТ. В Республике Ингушетия 178 (75,7\%) респондентов, в Чеченской Республике-44 (18,7\%), в Республике Дагестан-13 (5,5\%), всего 235 респондентов.

${ }^{16}$ Предложенная программа: 1.Внести изменения в ч. 1 ст.51 Конституции РФ следующего содержания: «Никто не обязан свидетельствовать против себя самого, своего супруга и близких родственников, круг которых определяется федеральным законом, за исключением случаев совершения преступлений террористического характера». 2. Принять Федеральный закон «О борьбе с организованной преступностью». 3.Ввести изменения в ФЗ о выплате вознаграждения за информацию о финансировании терроризма. 4. Ввести изменения в Ф3 и не выдавать трупы лиц, совершивших любое преступление террористического характера. 5. Объявить амнистию (или обеспечить необходимую охрану) лицам, финансировавшим терроризм под угрозой убийства, в том числе близких родственников, если они будут изобличать в ходе следствия и на суде участников организованных преступных формирований террористического характера. Что можете еще добавить?
Во взаимодействии с Росфинмониторингом по борьбе с финансированием терроризма необходимо менять: улучшить качество информаций и материалов по операциям с денежными средствами в наличной форме, поступающих из Росфинмониторинга и его межрегиональных управлений в правоохранительные органы в соответствии со ст.8 Федерального закона от 07.08.2001 №115-Ф3 «О противодействии легализации (отмыванию) доходов, полученных преступным путем, и финансированию терроризма» - 125 (12,5\%), увеличить количество информаций и материалов по операциям с денежными средствами в наличной форме, поступивших из Росфинмониторинга и его межрегиональных управлений в правоохранительные органы в соответствии со ст.8 Федерального закона от 07.08.2001 №115-Ф3 «О противодействии легализации (отмыванию) доходов, полученных преступным путем, и финансированию терроризма» 105 (48,8\%), иное16 (7,4\%).

Критерием эффективной деятельности Росфинмониторинга по борьбе с финансированием терроризма должно быть: качество информаций и материалов по операциям с денежными средствами в наличной форме, поступающих из Росфинмониторинга и его межрегиональных управлений в правоохранительные органы -107 (48,9\%), количество уголовных дел, возбужденных по информациям и материалам по операциям с денежными средствами в наличной форме, поступивших из Росфинмониторинга и его межрегиональных управлений в правоохранительные органы в соответствии со ст.8 Федерального закона от 07.08.2001 №115-Ф3 «О противодействии легализации (отмыванию) доходов и финансированию терроризма» за 2005-2010 гг. - 87 (39,7\%), количество информаций и материалов по операциям с денежными средствами в наличной форме, поступивших из Росфинмониторинга и его межрегиональных управлений в правоохранительные органы 61 (27,9\%), иное 13 (5,9\%).

Респонденты указали следующие пути качественного улучшения деятельности Росфинмониторинга по борьбе с финансированием терроризма: Разработать системы показателей для проведения различий между операциями с денежными средствами в наличной форме, характеризующих финансирование терроризма и операциями с денежными средствами в наличной форме, характеризующих отмывание денег - 78 (36,1\%), разработать системы показателей для проведения различий между операциями с денежными средствами в наличной форме, характеризующих 


\section{Национальная безопасность 2(25) • 2013}

финансирование терроризма и обычными операциями с денежными средствами в наличной форме - 78 $(36,1 \%)$, наделить Росфинмониторинг полномочиями субъекта ОРД 57 (26,4\%), разработать систему показателей (виды операций, финансовых инструментов и т.д.), характеризующих финансирование терроризма - 54 (25,0\%), иное - $18(8,3 \%)^{17}$.

Взаимодействием с ФСБ России по борьбе с финансированием терроризма не удовлетворены 107 (48,2\%), удовлетворены только 88 (39,6\%) респондентов, иное - 27 (12,2\%).

Взаимодействием с МВД РФ (полицией) по борьбе с финансированием терроризма: не удовлетворены - 142 (63,7\%) респондентов, удовлетворены $55(24,7 \%)$, иное $26(11,7 \%)$.

\footnotetext{
${ }^{17} \mathrm{O}$ необходимости по всем преступлениям террористического характера, связанным с финансированием терроризма, вносить представления пришли к выводу 150 респондентов $(64,9 \%)$, против $63(27,3 \%)$, иное - 18 (7,8\%).

Пришли к выводу о том, что выявление каналов и источников финансирования является обязанностью: всех правоохранительных органов 140 (60,6\%), ФСБ России 56 (24,2\%), Росфинмониторинга 33 (14,3\%), Следственного аппарата МВД, ФСБ, Следственного Комитета РФ - 30 (13,0\%), субъектов ОРД - 31 (13,4\%), МВД РФ - $8(3,55)$, иное 4 (1,7\%).

О необходимости подготовки, наряду с открытым, секретного варианта «Методических рекомендаций по тактике и методике осуществления прокурорского надзора по выявлению и расследованию преступлений, связанных с финансированием терроризма», включающего обобщенные результаты ОРД, разведывательной и контрразведывательной деятельности, установленные каналы и источники финансирования, сведения о финансировании зарубежными террористическими организациями, пришли к выводу 176 (76,5\%) респондентов, против - 40 (17,4\%), иное - 14 (6,1\%).

Каналами доставки денежных средств являются: курьеры - мужчины105 (46,9\%), фанатичные приверженцы ваххабизма - 96 (42,9\%), курьеры- женщины - 82 (36,6\%), студенты, выезжающие на учебу в страны арабского мира - 46 (20,5\%), иное - 46 (20,5\%).

В выявлении каналов и источником финансирования терроризма поможет «Схема каналов и источников финансирования», составленная военными аналитиками Объединенной группировки сил (ОГВс) решили 159 или 71,0 респондентов, против $-41(18,3 \%)$, иное - 24 (10,7\%).

Известно понятие «хавала», как одном из внешних каналов финансирования терроризма, только 51 (22,4\%) респонденту, неизвестно - $167(73,2 \%)$, иное - $10(4,4 \%)$.

Необходимо в МР отразить имеющиеся сведения о «хавале» решили 168 (75,7\%) респондентов, против 30 (13,5), иное 24 (10,8\%). Содержание Доклада рабочей группы целевой группы по осуществлению контртеррористических мероприятий (ЦГОКМ). Борьба с финансированием терроризма. ООН. Октябрь 2009 г. неизвестно 177 (78,0 \%) респондентов, известно 41 (18,1\%), иное $-9(4,0 \%)$.
}

По каждому факту проверки оперативной информации, связанной с финансированием терроризма, необходимо готовить специальную систему вопросов (применительно к свидетелю, подозреваемому, обвиняемому, источнику информации, правоохранительному органу, представившему оперативную информацию и т.д.): с этим утверждением согласились 189 (83,6\%) респондентов, не согласились $21(9,3 \%)$, иное $16(7,1 \%)$.

По каждому факту проверки оперативной информации, связанной с финансированием терроризма, необходимо использовать, как минимум «Криминолого-криминалистический стандарт вопросов по проверке оперативной информации о финансировании организованной террористической деятельности», разработанный в НИИ: с этим согласились 166 (73,8\%)респондентов, не согласились 38 (16,9\%), иное мнение- 21 (9,3\%).

С утверждением о том, что нужен криминологокриминалистический стандарт вопросов по проверке оперативной информации о финансировании организованной террористической деятельности» согласились 166 (73,5\%), против -49 (21,7\%), иное 11 (4,9\%).

Оперативно-боевые мероприятия, проводимые правоохранительными органами и спецслужбами России являются одним из источников информации о каналах и источниках финансирования терроризма. На вопрос о том, получаете ли Вы от оперативных подразделений правоохранительных органов и спецслужб эти сведения, документы отрицательно ответили 117 (52,5\%) респондентов, положительно 80 (35,9\%), иное - 26 (11,7\%).

Наемники и эмиссары международных террористических организаций являются одним из каналов финансирования терроризма. На вопрос о том, получаете ли Вы от оперативных подразделений правоохранительных органов и спецслужб РФ возможность допросов этих лиц, или работы с документами наемников-финансистов, отрицательно ответили 139 (62,1\%) респондентов, положительно - 61 (27,2\%), иное 24 (10,7\%).

Одним из способов выявления каналов и источников финансирования террористической деятельности является направление заданий на оперативную разработку в места лишения свободы лиц, которые отбывают наказание за совершенные террористические и иные преступления. В исправительных учреждениях (далее - ИУ) УИС ФСИН России в настоящее время отбывают наказание 824 лица, осужденных за преступления террористического характера. На 


\section{Оперативное реагирование и тактика действий}

вопрос о том, направляете ли Вы такие поручения, отрицательно ответили 127 (58,3\%) респондентов, положительно 56 (25,7\%), иное мнение- $35(16,1 \%)^{18}$.

${ }^{18}$ На вопрос о том, почему не направляете поручения на оперативную разработку в места лишения свободы лии, которые отбывают наказание за совершенные террористические $и$ иные преступления респонденты ответили так: этим должны заниматься оперативные подразделения правоохранительных органов и спеислужб 111 (53,1\%), низкая подготовка оперативного состава в ИУ - 52 (24,9\%), иное - 42 (20,1\%), большая следственная нагрузка- $16(7,7 \%)$.

На вопрос о том, необходимо ли направление кратких электронных фабул приостановленных уголовных дел террористического характера из Следственных управлений субъектов СКФО Следственного комитета РФ, Управлений ФСБ России в оперативные управления УФСИН субъектов РФ для оперативной разработки конкретных осужденных за преступления террористического характера в иелях раскрытия преступления террористического характера и их финансирования, положительно ответили 167 респондентов (77,0\%), отрицательно - 34 (15,7\%), иное -16 (7,4\%).

На вопрос о том, что необходимо сотрудникам оперативных подразделений УФСИН субъектов РФ для раскрытия приостановленных уголовных дел террористического характера и их финансирования респонденты ответили так: специальная подготовка сотрудников оперативных подразделений УФСИН - 120 (54,3\%), задания из оперативных подразделений МВД и ФСБ России 60 (27,1\%), спецаппарат из числа лии, проживающих на Северном Кавказе 57 (25,8\%), командировка на Северный Кавказ сотрудников оперативных подразделений для последующей организаичи работы по этой категории уголовных дел - 33 (14,9\%), специиальная литература по проблемам борьбы с терроризмом и его финансированием 120 (54,3\%), иное 17 (7,7\%).

На вопрос о том, как часто поступают в оперативные подразделения УФСИН РФ оперативные задания по раскрытию приостановленных уголовных дел террористического характера и их финансирования, респонденты ответили так: иное 64 (32,7\%), редко 61 (31,1\%), сотрудники УФСБ работают автономно с осужденными, никаких заданий не дают - 28 (14,3\%), часто - 19 (9,7\%).

Лииа, осужденные за преступления террористического характера на оперативную обстановку в ИУ, СИЗО : не влияют ответили -61 $(31,1 \%)$ респондентов, иное - 24 (12,2\%), влияют - 19 (9,7\%).

Возможно ли осужденному за преступление террористического характера стать лидером криминальной среды в колонии, положительно ответили $112(51,4 \%)$, отрицательно - 64 (29,4\%), иное - 42 (19,3\%).

На вопрос о том, какое отношение лидеров криминальной среды («воров в законе», смотрящих, положенцев) к лицам, осужденным за преступления террористического характера и их финансирование респонденты ответили следующим образом: поддерживают отношения 73 (35,4\%), иное - 63 (30,6\%), никаких отношений - 61 (29,6\%), по просьбе других осужденных на лии, осужденных за преступления террористического характера, приходят посылки и бандероли из России - 9 (4,4\%). Возможно ли единение лидеров криминальной средь и лии,

\section{1. Общие положения}

1.Настоящая Программа-Рекомендация (далее ПР) подготовлены на основании п. 4 приказа Генерального прокурора от 19.01.2010 №11 «Об организации прокурорского надзора за исполнением законов о противодействии легализации (отмыванию) доходов, полученных преступным путем, и финансированию терроризма») $)^{19}$.

1.2. Под финансированием терроризма понимается предоставление или сбор средств либо оказание финансовых услуг с осознанием того, что они предназначены для финансирования организации, подготовки или совершения хотя бы одного из преступлений, предусмотренных статьями 205, 205.1, 205.2, 206, 208, 211, 220, 221, 277, 278, 279 и 360 настоящего Кодекса, либо для обеспечения организованной группы, незаконного вооруженного формирования, преступного сообщества (преступной организации), созданных или создаваемых для совершения хотя бы одного из указанных преступлений ${ }^{20}$.

1.3. Правовую основу Программы-рекомендации составляют Конституция Российской Федерации, Федеральный закон «О прокуратуре Российской Федерации» от 17.01.1992 № 2202-1; Федеральный закон «Об оперативно-розыскной деятельности» от 12.08. 1995 № 144-Ф3; Уголовно-процессуальный кодекс Российской Федерации; Уголовный кодекс Российской Федерации, Концепция противодействия терроризму в Российской Федерации, утверждена

осужденных за террористические преступления и выступление против администрации, респонденты ответили так: да, возможно -126 (60,0\%), нет, невозможно - 45 (21,4\%), иное - $39(18,6 \%)$.

В целях улучшения оперативной работы с лицами, осужденными за преступления террористического характера, целесообразно их всех сконцентрировать в одной-двух тюрьмах. Согласны с этим предложением $91(41,4 \%)$ респондентов, не согласны - 106 (48,2\%), иное - 23 (10,5\%).

${ }^{19}$ Словарь иностранных слов. М. Русский язык. 1989. С.315. Методика - 1) совокупность методов, приемов целесообразного проведения какой-либо работы, 2) отрасль педагогической науки, исследующая закономерности обучения определенному учебному предмету (методика языка, методика арифметики). ${ }^{20}$ Примечание 1 к статье 205-1 УК РФ дано в новой редакции Федерального закона от 27.07.2010 №197-Ф3, перечень террористических статей дополнен 2 статьями: Ст.220 УК РФ Незаконное обращение с ядерными материалами или радиоактивными веществами и 221 УК РФ Хищение либо вымогательство ядерных материалов или радиоактивных веществ внесены в примечание 1 ст. 205.1 УК РФ. Изменения вступили в действие 29.10.2010 года. 


\section{Национальная безопасность 2(25) • 2013}

Президентом Российской Федерации 5 октября 2009 года; Федеральный закон «О противодействии терроризму», от 06.03.2006 № 35-Ф3; Федеральный закон «О противодействии экстремистской деятельности» от 25.07.2002 № 114-Ф3; Федеральный закон «О противодействии легализации (отмыванию) доходов, полученных преступным путем, и финансированию терроризма» от 07.08.2001 № 115-Ф3; Федеральный закон «О государственной защите потерпевших, свидетелей и иных участников уголовного судопроизводства», от 20.08.2004 № 119-Ф3, Федеральный закон от 27 декабря 2009 г. №349-Ф3 «О ратификации Договора государств - участников Содружества Независимых Государств о противодействии легализации (отмыванию) преступных доходов и финансированию терроризма (Душанбе, 5 октября 2007 г. $)^{21}$.

Более детально механизм реализации полномочий прокурора в этой сфере предусмотрен ведомственными и межведомственными нормативными правовыми актами, регламентирующими прокурорский надзор за исполнением законов в оперативнорозыскной деятельности и процессуальной деятельностью органов дознания и предварительного следствия: Приказ Генерального прокурора Российской Федерации от 02.06.2011 № 162 «Об организации прокурорского надзора за процессуальной деятельностью органов предварительного следствия», Приказ Генпрокуратуры РФ от 05.09.2011 N 277 «Об организации прокурорского надзора за исполнением законов при приеме, регистрации и разрешении сообщений о преступлениях в органах дознания и предварительного следствия», Приказ Генерального прокурора Российской Федерации от 15.02.2011 № 33 «Об организации надзора за исполнением Федерального закона «Об оперативно-розыскной деятельности», Приказ Генерального прокурора Российской Федерации от 07.12.2007 № 195 «Об организации прокурорского надзора за исполнением законов, соблюдением прав и свобод человека и гражданина», Приказ Генерального прокурора Российской Федерации Ф от 22.10.2009 № 339 «Об организации прокурорского надзора за исполнением

\footnotetext{
${ }^{21}$ Федеральный закон от 27 декабря 2009 г. №349-Ф3 «О ратификации Договора государств - участников Содружества Независимых Государств о противодействии легализации (отмыванию) преступных доходов и финансированию терроризма». Принят Государственной Думой 18 декабря 2009 года, Одобрен Советом Федерации 25 декабря 2009 года, ратифицированный Российской Федерацией 23.01.2010 г.
}

законодательства о противодействии терроризму», Приказ Генерального прокурора Российской Федерации от 19.01.2010 № 11 «Об организации прокурорского надзора за исполнением законов о противодействии легализации (отмыванию) доходов, полученных преступным путем, и финансированию терроризма», Приказ Генеральной прокуратуры РФ от 16 июля 2010 г. №284 «О порядке представления специальных донесений и иной обязательной информации», приказ Генеральной прокуратуры РФ от 9 сентября 2002 г. №249 «Об организации деятельности военных прокуратур Объединенной группировки войск (сил) на Северном Кавказе», приказ Генеральной прокуратуры РФ от 20 ноября 2002 г. №301 «О совершенствовании прокурорского надзора за соблюдением прав и свобод человека и гражданина при проведении контртеррористических операций на территории Северо - Кавказского региона Российской Федерации», приказ Главной военной прокуратуры РФ от 30 июня 2002 г. №180 «О порядке представления оперативной и иной обязательной информации в органах военной прокуратуры (с изменениями и дополнениями, внесенными приказом ГВП от 16.09.2002 №254, Указание Генерального прокурора РФ и директора Федеральной службы безопасности РФ от 18 апреля 2002 года N 20-27/10 «О порядке осуществления прокурорского надзора за исполнением Федерального закона «Об оперативно-розыскной деятельности» органами федеральной службы безопасности»), Указание Генеральной прокуратуры РФ, ФСБ РФ и МВД РФ от 25 апреля, 28 мая, 14 июня 2002 г. N 30/20, 15, 3 «О порядке взаимодействия дежурных служб Генеральной прокуратуры, Министерства внутренних дел и Федеральной службы безопасности РФ», Инструкция о порядке представления результатов оперативно-розыскной деятельности дознавателю, органу дознания, следователю, прокурору или в суд, утвержденной совместным приказом Генерального прокурора, МВД, ФСБ, ФСО, ФТС, СВР, ФСИН, ФСКН, МО России от 17.04.2007 № 368/185/164/481/32/184/97/147, Указание «О порядке представления органами внутренних дел оперативно-служебных документов с целью осуществления прокурорами надзора за исполнением Федерального закона «Об оперативно-розыскной деятельности», утвержденное совместным приказом Генерального прокурора РФ № 215/69, МВД РФ № 1/7818 от 29.09.2008; Указание Генерального прокурора Российской Федерации от 29.01.2008 
№ 14/49 «Об усилении прокурорского надзора за исполнением требований закона о соблюдении подследственности уголовных дел», Указание Генерального прокурора Российской Федерации от 05.12.2007 № 193/27 «О порядке направления в Федеральную службу по финансовому мониторингу сведений по вопросам противодействия финансированию экстремистской и террористической деятельности» (в редакции приказа ГП РФ от 05.08.2011 №235), Указание Генерального прокурора РФ от 11.02.2008 № 24/49 «О порядке реализации отдельных положений Инструкции по организации информационного обеспечения сотрудничества по линии Интерпола».

1.4. В п. 21. Концепции противодействия терроризму в Российской Федерации к основным мерам по предупреждению (профилактике) терроризма, наряду, с политическими и социально-экономическими, относятся правовые (реализация принципа неотвратимости наказания за преступления террористического характера, незаконный оборот оружия, боеприпасов, взрывчатых веществ, наркотических средств, психотропных веществ и их прекурсоров, радиоактивных материалов, опасных биологических веществ и химических реагентов, финансирование терроризма, а также регулирование миграционных процессов и порядка использования информационно-коммуникационных систем).

Таким образом, правоохранительные органы и спецслужбы России, имея современную правовую основу борьбы с терроризмом и его финансированием, совершенствуя ее на основе научных исследований и практики, координируя и взаимодействуя с правоохранительными органами и спецслужбами других государств, могут добиться повышения эффективности этой борьбы.

\section{Библиография:}

1. “Модельный закон о противодействии финансированию терроризма”. Информационный бюллетень. Межпарламентская Ассамблея государств-участников Содружества Независимых Государств. 2007. N 39 (часть 1). С. 254 - 281. Принят в г. Санкт-Петербурге 16.11.2006 Постановлением 27-6 на 27-ом пленарном заседании Межпарламентской Ассамблеи государствучастников СНГ.
2. Выборочные данные из формы 282 за январьиюнь 2011 года. Раздел 2. Сведения о преступлениях, связанных с террористической деятельностью.

3. Федеральный закон от 07.08.2001 N 115-Ф3 (ред. от 27.06.2011) “О противодействии легализации (отмыванию) доходов, полученных преступным путем, и финансированию терроризма"'(в ред. Федеральных законов от 25.07.2002 N 112-Ф3, от 30.10.2002 N 131-Ф3, от 28.07.2004 N 88-Ф3, от 16.11.2005 N 145Ф3, от 27.07.2006 N 147-Ф3, от 27.07.2006 N 153-ФЗ, от 12.04.2007 N 51-Ф3, от 19.07.2007 N 197-ФЗ, от 24.07.2007 N 214-Ф3, от 28.11.2007 N 275-Ф3, от 03.06.2009 N 121-Ф3, от 17.07.2009 N 163-Ф3, от 05.07.2010 N 153-Ф3, от 23.07.2010 N 176-Ф3, от 27.07.2010 N 197Ф3, от 27.06.2011 N 162-Ф3). Первоначальный текст документа опубликован в изданиях “Российская газета", N 151-152, 09.08.2001, “Собрание законодательства РФ”, 13.08.2001, N 33 (часть I), ст. 3418.

4. Мельник Т. В. Международно-правовое регулирование борьбы с финансированием терроризма на универсальном уровне. Автореферат. Москва.2010.

5. Ульянова В.В. Противодействие финансированию терроризма. Автореферат диссертации на соискание ученой степени кандидата юридических наук: Свердловск. 2010.

6. Сводный отчет по России »О преступлениях террористического характера, экстремистской направленности и связанных с террористической деятельностью за январь-июнь 2011 года».

7. Приложение № 1 к приказу Генерального прокурора Российской Федерации от 28.05.2010 № 226. Сведения о работе прокурора по надзору за исполнением законов о федеральной безопасности, межнациональных отношениях и противодействии экстремизму и о результатах расследования уголовных дел экстремистской и террористической направленности за январь-июнь 2011 года (нарастающим итогом).

8. Вестник Национального антитеррористического комитета. Специальный выпуск. №2 (4).2011. С.12. Из доклада Директора ФСБ России А.В. Бортникова.

9. Федеральный закон от 27 декабря 2009 г. №349-Ф3 “О ратификации Договора 
DOI: $10.7256 / 2073-8560.2013 .02 .4$

Национальная безопасность 2(25) • 2013

государств - участников Содружества Независимых Государств о противодействии легализации (отмыванию) преступных доходов и финансированию терроризма”. Принят Государственной Думой 18 декабря 2009 года, Одобрен Советом Федерации 25 декабря 2009 года, ратифицированный Российской Федерацией 23.01.2010 г.

\section{References (transliteration):}

1. Mel'nik T. V. Mezhdunarodno-pravovoe regulirovanie bor'by s finansirovaniem terrorizma na universal'nom urovne. Avtoreferat. Moskva.2010.

2. Ul'yanova V.V. Protivodeystvie finansirovaniyu terrorizma. Avtoreferat dissertatsii na soiskanie uchenoy stepeni kandidata yuridicheskikh nauk: Sverdlovsk. 2010. 